UDC 338.48

JEL Classification: R10, R11

DOI: $10.15587 / 2706-5448.2021 .237162$ Article type «Reports on Research Projects»

\section{Liudmyla Matviichuk, Iryna Karpiuk}

\title{
SEARCH FOR PROSPECTS FOR THE DEVELOPMENT OF THE HOTEL BUSINESS ON THE EXAMPLE OF THE REGIONS OF UKRAINE
}

The object of research is the processes of development of the hotel industry, as one of the most important elements of the tourist infrastructure of the regions. Let's consider these processes using the example of the regions of Ukraine. One of the most problematic areas for the development of the hotel industry in the regions of Ukraine is the quality of hotel services and the condition of hotel rooms, which often do not meet international standards and norms. The number of business entities in the hotel business in Ukraine, in comparison with European countries, is also insignificant and during the period of large-scale events in the regions does not meet the demand for hotel services.

In the work, research methods were used, which made it possible to determine the problem areas of the development of the hotel industry in the regions of Ukraine and propose ways to solve them. For example, to determine the content of the definition of «quality of hotel services», let's use the method of generalization and systematization, to analyze the state and development of the hotel industry in the regions of Ukraine, let's use the analytical method, etc.

In the course of the study, a platform for the development of the hotel industry at the regional level was developed, taking into account the trends in the regional development of the hotel industry. This is due to the fact that the proposed process approach to the development of the studied processes has a number of advantages, in particular, the proposed software platform for the development of the hotel industry at the regional level provides for the choice of regional strategies for the development of the processes under study, taking into account the regional characteristics of the activities of hotel enterprises.

Thanks to this approach, it is possible for hotel enterprises in the regions to unite into hotel or tourist clusters, hospitality associations, etc., in accordance with the presence in Ukraine of regions of leaders and regions of outsiders in the development of the hotel industry. Accordingly, the results can be useful both for the regions of Ukraine and beyond its borders, for better understanding and management in the current conditions of the pandemic.

Keywords: regional development of the hotel industry, quality of hotel services, state of the hotel business.

\section{How to cite}

Matviichuk, L., Karpiuk, I. (2021). Search for prospects for the development of the hotel business on the example of the regions of Ukraine. Technology Audit and Production Reserves, 4 (4 (60)), 24-28. doi: http://doi.org/10.15587/2706-5448.2021.237162

\section{Introduction}

The pandemic had a destructive effect on the activities of the entire service sector and made its own adjustments. So, in 2020, almost the entire hospitality industry came to a standstill, the profits of hotel enterprises fell catastrophically. The pandemic has made its own adjustments to the development of all types of economic activity in the world. The hospitality industry suffered serious losses, the largest losses were typical for the hotel industry. Rebuilding the hospitality industry requires significant economic and time resources. Considering the above, it is necessary to analyze the state and prospects for the development of the hotel industry, which we will do on the example of the regions of Ukraine.

The economic processes that are taking place in Ukraine and in the world over the past two years have had the greatest impact on the hospitality sector, including the state and development of the hotel industry. By the spread of the COVID-19 pandemic, hotel operations were quite a lucrative business both in Ukraine and in the world. The fallout from this pandemic, such as travel bans and border closures, have led many hospitality businesses to either restrict or close their operations. The hospitality business lost millions in revenue thanks to unprecedented efforts to combat the pandemic. It is estimated [1] that 75,000,000 jobs and a turnover of 2.1 trillion USD are at risk.

Previous research by scientists has investigated the impact of various epidemics on tourism and hospitality, such as swine flu in the UK [2] and SARS in China [3]. Recent studies have also examined the impact of the COVID-19 pandemic. For example, [4] investigated how COVID-19 changed society, economy and tourism compared to other pandemics. 
The authors of [5] investigated the impact of the COVID-19 pandemic on the lifestyle and travel preferences of Chinese citizens. And in [6], the issues of socialization of tourism after the COVID-19 pandemic are investigated.

The level of complexity faced by the hotel business due to the pandemic is high, as it is a combination of the typology of natural disasters and crises. Scientists note the need to use complexity theories to solve this problem [7]. It has also been suggested that complexity theory may be useful for studying the complex nature of hotel crises and disasters at various scales [8].

Most of the scientific works have an analytical direction and are devoted to the general characteristics of the development of the hotel industry [9, 10], not counting the modern factors of influence on the state and development of the studied processes in the context of regions, especially in the context of the spread of the COVID-19 pandemic. Therefore, more research is needed to understand the impact of the COVID-19 pandemic on the hospitality industry.

Thus, the object of research is the processes of development of the hotel industry, as one of the most important elements of the tourist infrastructure of the regions. The purpose of the work is to find ways to improve the current state of the level of development of the hotel industry, by forming a unified platform for the processes under study at the regional level.

\section{Methods of research}

The study used the following methods:

- generalization and systematization (to determine the content of the definition of «quality of hotel services»);

- analytical (to analyze the state and development of the hotel industry in the regions of Ukraine);

- grouping (to determine the factors of influence on the investigated processes);

- comparison (for a comparative analysis of the investigated processes in the regions of the country and in dynamics);

- process approach (for the development of a software platform for the development of the hotel industry at the regional level);

- graphic (for the formation of a graphic display of the dynamics of the development of the hotel industry).

\section{Research results and discussion}

The spread of the pandemic, over the last period, has carried out a powerful destructive effect on all spheres of economic activity and all regions of Ukraine, without exception. The hospitality industry suffered serious losses, the largest losses were typical for the hotel industry. Rebuilding the hospitality industry requires significant economic and time resources.

The study analyzed the regional state and development of the hotel industry in Ukraine. So, recently, the hotel industry has been built at a rapid pace in the regions of Ukraine. Now there is a tendency towards the closure and curtailment of the activities of hotel enterprises. However, hotel businesses are being replaced by temporary accommodation facilities that provide accommodation for tourists for a short period of time during seasonal festivals, concerts and the like.

So, in Ukraine in 2019, the number of hotels and similar accommodation facilities was sufficient. In 2015, the number of hotel enterprises, compared to 2011, decreased by almost $22 \%$, and compared to 2013, which accounted for the largest number of hotels during the study period by $30 \%$.

In general, despite the general trend towards a decrease in the number of accommodation facilities, there are regions in which this indicator, on the contrary, has grown. In some regions of Ukraine, the number of hotel enterprises remained unchanged.

In order to determine the leading regions and outsider regions, let's propose to determine the growth indices. For example, let's consider statistical data on the development of the hotel industry. Such dynamics of the development of the hotel industry in the regions of Ukraine for 2018-2019 is presented in Table 1.

Dynamics of development of the hotel industry in the regions of Ukraine in 2018-2019

\begin{tabular}{|c|c|c|c|c|c|c|}
\hline \multirow[b]{2}{*}{ Region } & \multicolumn{3}{|c|}{ Number of hotel facilities } & \multicolumn{3}{|c|}{ Number of places } \\
\hline & 2018 & 2019 & $\begin{array}{l}\text { Growth } \\
\text { index }\end{array}$ & 2018 & 2019 & $\begin{array}{l}\text { Growth } \\
\text { index }\end{array}$ \\
\hline Vinnytsia & 22 & 21 & -1 & 1895 & 1869 & -26 \\
\hline Volyn & 72 & 61 & -11 & 3684 & 3309 & -375 \\
\hline Dnipropetrovsk & 93 & 106 & 13 & 11826 & 13070 & 1244 \\
\hline Donetsk & 78 & 88 & 10 & 9505 & 10884 & 1379 \\
\hline Zhytamyr & 17 & 19 & 2 & 995 & 1615 & 620 \\
\hline Zakarpattia & 54 & 59 & 5 & 3748 & 4672 & 924 \\
\hline Zaporizhzhia & 123 & 133 & 10 & 16102 & 17938 & 1836 \\
\hline Ivano-Frankivsk & 67 & 64 & -3 & 6229 & 5912 & -317 \\
\hline Kyiv & 86 & 96 & 10 & 9489 & 10184 & 695 \\
\hline Kirovohrad & 30 & 37 & 7 & 2114 & 2377 & 263 \\
\hline Luhansk & 9 & 11 & 2 & 869 & 952 & 83 \\
\hline Lviv & 129 & 130 & 1 & 13191 & 13188 & -3 \\
\hline Mykolaiv & 102 & 103 & 1 & 12620 & 12081 & -539 \\
\hline Odesa & 177 & 187 & 10 & 23427 & 26151 & 2724 \\
\hline Poltava & 43 & 44 & 1 & 3363 & 3453 & 90 \\
\hline Rivne & 17 & 18 & 1 & 1557 & 1588 & 31 \\
\hline Sumy & 21 & 21 & 0 & 1532 & 1424 & -108 \\
\hline Ternopil & 14 & 15 & 1 & 1267 & 1392 & 125 \\
\hline Kharkiv & 67 & 73 & 6 & 7511 & 7824 & 313 \\
\hline Kherson & 107 & 88 & -19 & 19581 & 16594 & -2987 \\
\hline Khmelnytskyi & 33 & 31 & -2 & 2823 & 2606 & -217 \\
\hline Cherkasy & 54 & 55 & 1 & 3978 & 4308 & 330 \\
\hline Chernivtsi & 11 & 13 & 2 & 1325 & 2108 & 783 \\
\hline Chernihiv & 25 & 24 & -1 & 1949 & 1722 & -227 \\
\hline $\begin{array}{l}\text { Autonomous } \\
\text { Republic of Crimea }\end{array}$ & $\begin{array}{c}\text { No data } \\
\text { available }\end{array}$ & $\begin{array}{l}\text { No data } \\
\text { available }\end{array}$ & $\begin{array}{l}\text { No data } \\
\text { available }\end{array}$ & $\begin{array}{l}\text { No data } \\
\text { available }\end{array}$ & $\begin{array}{l}\text { No data } \\
\text { available }\end{array}$ & $\begin{array}{l}\text { No data } \\
\text { available }\end{array}$ \\
\hline Kyiv city & 140 & 129 & -11 & 20662 & 19619 & -1043 \\
\hline Total & 1591 & 1626 & 35 & 181242 & 186840 & 5598 \\
\hline
\end{tabular}

Note: compiled on the basis of data from [11] 
So, the leading regions include: Dnipropetrovsk, Donetsk, Zaporizhzhia, Kyiv and Odesa regions, and the outsider regions include: Kherson, Volyn, Mykolaiv regions, and Kyiv.

During 2018-2019 it is possible to track the dynamics of growth in the number of hotel accommodation facilities. This is due to the fact that some regions are rapidly developing as a popular tourist center, the number of foreign and domestic tourists is growing and there is a need for entrepreneurs to increase the number of beds.

Insufficient in Ukraine, in comparison with the leading countries in the development of tourism, the number of hotel enterprises. In 2019, 5,335 collective accommodation facilities operated in Ukraine. For example, there are about 27 thousand hotels in Great Britain, 20.5 thousand in France, more than 3.5 thousand in Romania. In the structure, according to the size of hotels in Europe, the number of large enterprises is $15-25 \%$ of their total number, $75-85 \%$ are family-type hotels and hotels. In Ukraine, about $70 \%$ of all places are concentrated by large hotels, and motels, campings, youth centers are typical in European countries, but small in number in Ukraine.

Taking into account the regional aspect of the study, let's propose to construct a Bar Chart reflecting the dynamics of the number of hotel facilities in the regions of Ukraine. Such a diagram provides a visual representation of the processes under study is presented in Fig. 1.

In 2019, compared to 2018, the number of hotels in Odesa, Zaporizhzhia, Dnipropetrovsk, Kirovohrad regions increased slightly, but increased. This can be explained by the development of the hospitality industry. A significant reduction in the hotel stock took place in Donetsk and Luhansk regions, which are on the line of demarcation with the partially occupied territories controlled by Ukraine. The situation is similar with the temporarily occupied Autonomous Republic of Crimea, where since 2011 there has been an increase in the number of hotels and similar accommodation facilities, however, since 2014, no information is available.

It is also important to trace the dynamics of the number of rooms in hotels by regions in Ukraine (Fig. 2).

Analysis of the number of rooms in hotels and similar accommodation facilities by regions of Ukraine, according to the State Statistics Service of Ukraine, showed significant regional disparities. The decrease in the number of beds occurred on the territory of the Mykolaiv, Kherson regions and the Kyiv city. However, an increase in the number of rooms in hotels was observed in Dnipropetrovsk, Zhytomyr, Zakarpattia, Zaporizhzhia, Kyiv, Kirovohrad, Odesa, Vinnytsia and Cherkasy regions. On the territory of other regions, the dynamics of changes in the number of beds remains practically constant.

After analyzing the state and development of the hotel industry in Ukraine, it can be argued that there were twenty-four rooms per hotel. The functional structure of the hotel industry in Ukraine is represented not only by hotel enterprises, but also by motels, hotel and office centers, campings, youth hostels and mountain shelters, hostels for visitors and other places for short-term accommodation. Of these, hotels account for $60.9 \%$, motels - $5 \%$, hostels - $1.2 \%$, campgrounds $0.2 \%$, hostels $-4.2 \%$, other places for temporary accommodation - $28.5 \%$.

Thus, the hospitality industry is one of the components of the hospitality industry that has suffered the greatest losses. The hospitality business is the most related to the eventual measures of the regions, did not take place or were moved online due to the pandemic. It is hotels and other collective accommodation facilities related to the tourism sector than other economic entities (restaurants, entertainment industry, etc.) that have a much wider range of services.

It is also worth emphasizing that an important factor in the development of the hotel industry in the region is the issues of standardization, certification, classification or categorization of hotel facilities. Voluntary certification in Ukraine is dealt with by the National Tourism Organization together with the World Tourism Organization. So, for the hospitality industry business, a series of protocols for the main activities of the Ukrainian hospitality industry were presented in order to effectively mitigate the consequences of the COVID-19 pandemic [12].

On the website of the National Tourism Organization, there is free access to Methodological Recommendations for improving the quality of tourist and hotel services in Ukraine (including hotel services), achieving orderliness of actions in the work of hospitality subjects, in particular, by classifying them [12].

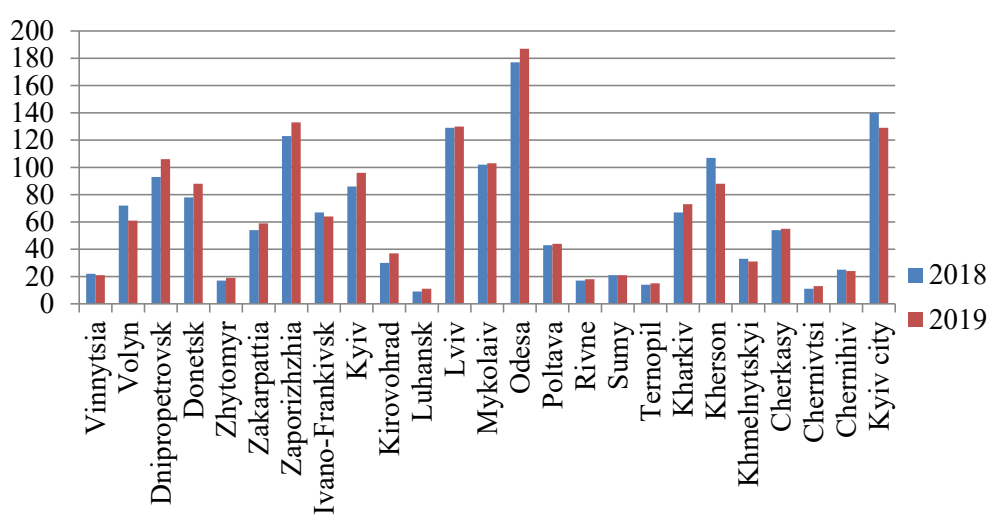

Fig. 1. Dynamics of the number of hotels in the regions of Ukraine for the period 2018-2019 (built on the basis of data [11])

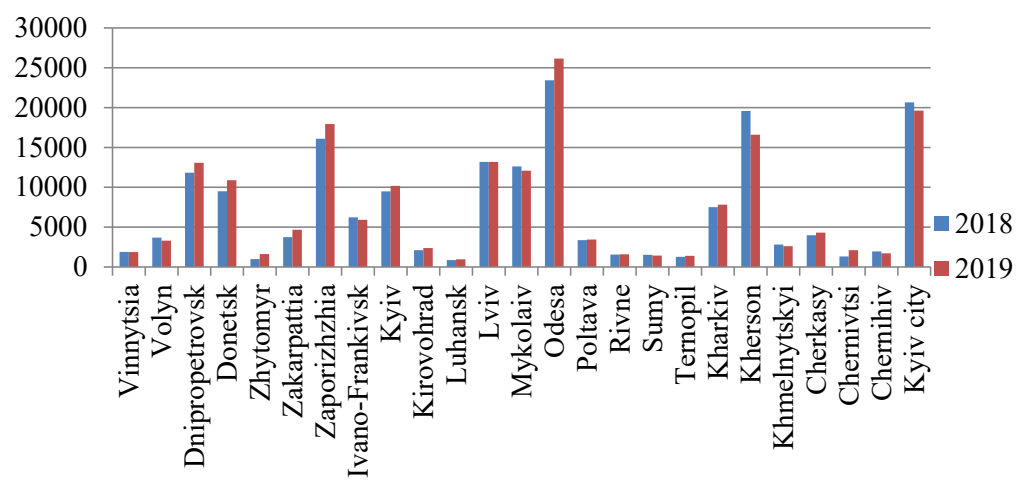

Fig. 2. Dynamics of the number of rooms in hotels in the regions of Ukraine for the period 2018-2019 (built on the basis of data [11]) 
Methodological recommendations are an unofficial translation of international standards, in case of ambiguous interpretation of the requirements of these documents, it is recommended to use the corresponding international standards ISO and EN. The recommendations are aimed at voluntary application by all interested enterprises, organizations and individual entrepreneurs. It should be noted that the National Tourism Organization of Ukraine has introduced a special award «Safe travels».

Another important component of the structural development of the elements of the hotel industry in the region is the availability of social resources in the form of qualified personnel who are specialists in hotel management and have the appropriate competencies. Thus, one of the main directions for improving the development of the hotel industry at the regional level is staff training.

Also, an important direction in the development of the area under study is the unification of similar establishments of the hotel industry into a network. The hotel association brings a number of benefits to both hotel guests and organizers. The advantages of such a combination are:

- saving resources (financial - on advertising, social -

on regular management units, etc.);

- reduction in overall costs;

- reduction of investment risks;

- expansion of areas of activity by entering new hotel markets.

The main disadvantages of chain hotels include:

- loss of individuality and identity;

- possibility of conflicts;

- loss of speed of response to emerging problems (due to scale), etc.

Analysis of international experience in the development of the hotel industry showed two key segments of the hotel services market (independent hotel enterprises and hotel chains). In view of the presence of leading regions and outsider regions in Ukraine, let's consider it expedient to offer hotel enterprises to unite in hotel or tourist clusters, hospitality associations, and the like.

The program platform for the development of the hotel industry at the regional level is presented in Table 2.

Determination of program objectives is one of the main components of the formation of a program platform for economic development at the regional level. According to the study, the main program objectives are: increasing the level of competitiveness of regional hotel services and creating a favorable institutional environment for the development of the hotel industry.

The choice of a regional strategy for the development of the hotel industry, taking into account the territorial characteristics, indicates the definition of appropriate strategies for the regions where there is an increase in the indicators of the hotel industry, as well as regions where there is a decline in the indicators of the hotel industry).

Thus, a breakthrough strategy can ensure the socioeconomic growth of the region through the development of the hospitality industry. This requires improving the quality of hotel services and bringing them into line with international norms and rules. The growth strategy is based on the use of the own potential of the hotel industry in the region and can increase their competitive advantages.

The proposed platform for the development of the hotel industry at the regional level is unified, provides for the choice of regional strategies for the development of the hotel industry, taking into account the territorial characteristics and the choice of appropriate strategies for the regions. In regions with positive dynamics, there is an increase in the quantitative indicators of the hotel industry, and in regions with negative dynamics, a decline in the indicators of the hotel industry can be traced.

Program platform for the development of the hotel industry at the regional level

\begin{tabular}{|c|c|c|}
\hline Key definitions & $\begin{array}{c}\text { Aegions with positive dynamics } \\
\text { Dnipropetrovsk, Donetsk, Zhytomyr, Zaporizhzhia, } \\
\text { Zakarpattia, Kirovohrad, Kyiv, Luhansk, Odesa, Kharkiv, } \\
\text { Cherkasy and Chernivtsi regions }\end{array}$ & $\begin{array}{c}\text { Regions with negative dynamics } \\
\text { Vinnytsia, Volyn, Ivano-Frankivsk, Kherson, Khmelnytsky, Chernihiv } \\
\text { regions, and Kyiv }\end{array}$ \\
\hline Advantages & $\begin{array}{l}\text { - positive trends in the development of the hotel industry; } \\
\text { - a relatively wide range of hotel services; } \\
\text { - sufficient availability of resources for the development of } \\
\text { the hotel industry }\end{array}$ & $\begin{array}{l}\text { - favorable location of most regions; } \\
\text { - opportunity to participate in grant programs; } \\
\text { - sufficient resource potential }\end{array}$ \\
\hline Vision & $\begin{array}{l}\text { - formation of a regional standard for the quality of hotel } \\
\text { services }\end{array}$ & $\begin{array}{l}\text { - creation of a regional platform for communication of stakeholders in } \\
\text { the hotel industry }\end{array}$ \\
\hline Program objectives & - improving the quality level of regional hotel services & $\begin{array}{l}\text { - improving the institutional environment for the development of the } \\
\text { hotel industry in the region }\end{array}$ \\
\hline Choice of strategy & - breakout strategy & - building strategy \\
\hline Operational goals & $\begin{array}{l}\text { - formation of investment platforms to finance the develop- } \\
\text { ment of the hotel industry }\end{array}$ & $\begin{array}{l}\text { - development of projects for the development of the hospitality industry } \\
\text { in the region, in particular, the hotel industry }\end{array}$ \\
\hline \multirow[t]{2}{*}{$\begin{array}{l}\text { Areas of develop- } \\
\text { ment of the region }\end{array}$} & $\begin{array}{l}\text { - application of tools for the integration of regional hotel } \\
\text { services into the national and world economy; } \\
\text { - improving the tourist infrastructure in the regions; } \\
\text { - improving the specialization of hospitality enterprises; } \\
\text { - coordination of national and regional strategies for the } \\
\text { development of the hospitality industry }\end{array}$ & $\begin{array}{l}\text { - unification of hotel enterprises that are similar in structure and values; } \\
\text { - search for new organizational forms of management; } \\
\text { - formation and development of infrastructure in the regions; } \\
\text { - search for "points of growth»; } \\
\text { - modernization of the outdated hotel industry; } \\
\text { - formation of effective regional programs for the development of the } \\
\text { hospitality industry }\end{array}$ \\
\hline & \multicolumn{2}{|l|}{ - advanced training of hotel personnel } \\
\hline Type of development & - advanced & - overtake \\
\hline
\end{tabular}




\section{Conclusions}

In the course of the study of the development of the hotel industry on the example of the regions of Ukraine, the regions were grouped and identified according to two criteria: regions where there is an increase in quantitative indicators of the hotel industry or a decline. On the basis of the above, a platform for the development of the hotel industry at the regional level is proposed, which can ensure the socio-economic growth of regions by applying thoughtful measures and tools for the development of the processes under study.

In addition, it was proposed that hospitality enterprises unite into networks, hotel or tourist clusters, hospitality associations, and the like. New, mainly destructive factors of influence on the development of the hotel business, stimulate business entities to look for new approaches and models of doing business. A well-thought-out regional policy, the use of international experience, the introduction of innovative technologies in the development of hotel services, will allow hotel enterprises to adapt more quickly in modern, difficult conditions of development. But so far there is no legal basis for the creation of clusters, and this is not the only obstacle to the development of the hotel business. Therefore, to combine hotels in chains, tourist clusters, hospitality associations, etc. further research is needed on this issue.

The research results will be useful for the effective functioning of the hotel industry in all countries of the world. Now there has been a reorientation of the criteria for the quality of hotel services towards safety. Therefore, for the functioning of the hotel industry in all countries of the world, a flexible system of stimulating the processes under study is necessary, as well as improving the institutional foundations for the development of the hospitality industry.

\section{References}

1. World Travel $\mathcal{G}$ Tourism Council (WTTC). Available at: https:// wttc.org/About/About-Us/media-centre/press-releases/pressreleases/2020/latest-research-from-wttc-shows-an-increase-injobs-at-risk-in-travel-and-tourism
2. Page, S., Song, H., Wu, D. C. (2011). Assessing the Impacts of the Global Economic Crisis and Swine Flu on Inbound Tourism Demand in the United Kingdom. Journal of Travel Research, 51 (2), 142-153. doi: http://doi.org/10.1177/0047287511400754

3. Zeng, B., Carter, R. W., De Lacy, T. (2005). Short-term Perturbations and Tourism Effects: The Case of SARS in China. Current Issues in Tourism, 8 (4), 306-322. doi: http://doi.org/ $10.1080 / 13683500508668220$

4. Gössling, S., Scott, D., Hall, C. M. (2020). Pandemics, tourism and global change: a rapid assessment of COVID-19. Journal of Sustainable Tourism, 29 (1), 1-20. doi: http://doi.org/10.1080/ 09669582.2020 .1758708

5. Wen, J., Kozak, M., Yang, S., Liu, F (2020). COVID-19: potential effects on Chinese citizens' lifestyle and travel. Tourism Review, 76 (1), 74-87. doi: http://doi.org/10.1108/tr-03-2020-0110

6. Higgins-Desbiolles, F. (2020). Socialising tourism for social and ecological justice after COVID-19. Tourism Geographies, 22 (3), 610-623. doi: http://doi.org/10.1080/14616688.2020.1757748

7. Zenker, S., Kock, F. (2020). The coronavirus pandemic A critical discussion of a tourism research agenda. Tourism Management, 81. doi: http://doi.org/10.1016/j.tourman.2020.104164

8. Ritchie, B. W., Jiang, Y. (2019). A review of research on tourism risk, crisis and disaster management: Launching the annals of tourism research curated collection on tourism risk, crisis and disaster management. Annals of Tourism Research, 79. doi: http://doi.org/10.1016/j.annals.2019.102812

9. Davydova, O. Yu. (2017). The Formation of the System of Innovation Management of Development of Enterprises of HotelRestaurant Industry. Biznes-Inform, 11, 459-464.

10. Nezdoimynov, S. H. (2016). Hotel business of Ukraine in conditions of market reforms. Ars Administrandi, 3, 97-106.

11. Derzhavna sluzhba statystyky Ukrainy. Available at: http:// www.ukrstat.gov.ua/

12. Natsionalna turystychna orhanizatsiia Ukrainy. Available at: http:// www.ntoukraine.org/standardization_ua.html

Liudmyla Matviichuk, Doctor of Economic Sciences, Professor, Department of Economic and Social Geography, Lesya Ukrainka Volyn National University, Lutsk, Ukraine, ORCID: https://orcid.org/ 0000-0003-1694-6178

$\triangle$ Iryna Karpiuk, Postgraduate Student, Department of Entrepreneurship, Trade and Logistics, Lutsk National Technical University, Lutsk, Ukraine, e-mail: iryna.masechko@gmail.com, ORCID: https:// orcid.org/0000-0002-9887-1802

$\triangle$ Corresponding author 